\title{
A new species of Acantholimon Boiss. (Plumbaginaceae) from Ankara, Turkey
}

\author{
MUSA DOĞAN ${ }^{1 *}$ and GALIP AKAYDIN ${ }^{2}$ \\ ${ }^{1}$ Department of Biological Sciences, Middle East Technical University, 06531 Ankara, Turkey \\ ${ }^{2}$ Department of Biology Education, Hacettepe University, 06532 Beytepe, Ankara, Turkey
}

Received October 2001; accepted for publication May 2002

\begin{abstract}
Acantholimon anatolicum Dogan \& Akaydın sp. nov. (Plumbaginaceae) is described and illustrated. The species grows on deep gypsum-rich sandy soil on eroded mountain slopes between Çayırhan and Nallıhan in Ankara. Diagnostic morphological characters that discern it from closely related species are discussed and its conservation status is indicated. A revised key to Acantholimon species with \pm dense terminal spikes and excurrent scapes is given for the species found in Turkey. (c)The Linnean Society of London, Botanical Journal of the Linnean Society, 2002, 140, 443-448.
\end{abstract}

ADDITIONAL KEYWORDS: Central Anatolia - conservation - distribution.

\section{INTRODUCTION}

The genus Acantholimon Boiss. comprises about 200 species throughout the world but mainly distributed in Euro-Asia and crossing into South America. Its centre of diversity lies in the east Mediterranean and Irano-Turanian phytogeographic regions. Acantholimon species are all perennial, densely or laxly pulvinate subshrubs forming thorn cushions. The genus has ecological and economic importance. Its ornamental importance with coloured long-lasting flowers is remarkable. A Turkish dessert is also made by means of boiling the roots (Baytop, 1994).

Boissier (1879) recognized 74 species of Acantholimon in his Flora Orientalis; some of these species were described from Turkey. Bokhari (1970, 1972a) carried out taxonomic studies on Plumbaginaceae in Turkey where he recognized six genera (Acantholimon Boiss., Limoniopsis Lincz., Limonium Miller, Armeria Willd., Goniolimon Boiss. and Plumbago L.) in this family, and described six new species (A. confertiflorum, A. halophilum, A. reflexifolium, A.dianthifolium, A. hypochaerum and A. strigillosum). Bokhari (1972b) also studied the stigma and pollen types in Acantholimon and Limoniopsis. The first revision of Acantholi-

*Corresponding author. E-mail: doganm@metu.edu.tr mon in Turkey was done by Bokhari \& Edmondson (1982) for the Flora of Turkey and the East Aegean Islands in which they recognized 25 . They indicated the possibility of finding further species either imperfectly known (two species) or doubtfully recorded (nine species).

A recent study conducted by Muvaffak (1997) concluded that there were nine species of Acantholimon in Ankara Province, viz: A. venustum Boiss., A. halophilum Bokhari, A. acerosum (Willd.) Boiss., A. kotschyi (Jaub. \& Spach) Boiss., A. confertiflorum Bokhari, A.glumaceum (Jaub. \& Spach) Boiss., A. caesareum Boiss. \& Bal., A. puberulum Boiss. \& Bal. and A. ulicinum (Willd. et Schultes) Boiss. In a recent numeric taxonomic study, a new infrageneric grouping in the genus was made on the basis of the species found in Ankara Province, and three subsections, namely Caryophyllacea Bunge (including A. venustum and A. kotschyii), Halophiliacea Muvaffak \& Dogan (including A.halophilum, A. acerosum, A. caesareum and A. confertiflorum) and Androsacea Bunge (including A. glumaceum, A. puberulum and A. ulicinum) were recognized (Muvaffak, Doğan \& Bilgin, 2001).

The extensive field surveys and the laboratory studies conducted on Acantholimon in Turkey by the authors revealed four additional new species, namely A. avanosicum Dogan \& Akaydın (Doğan \& Akaydın, 

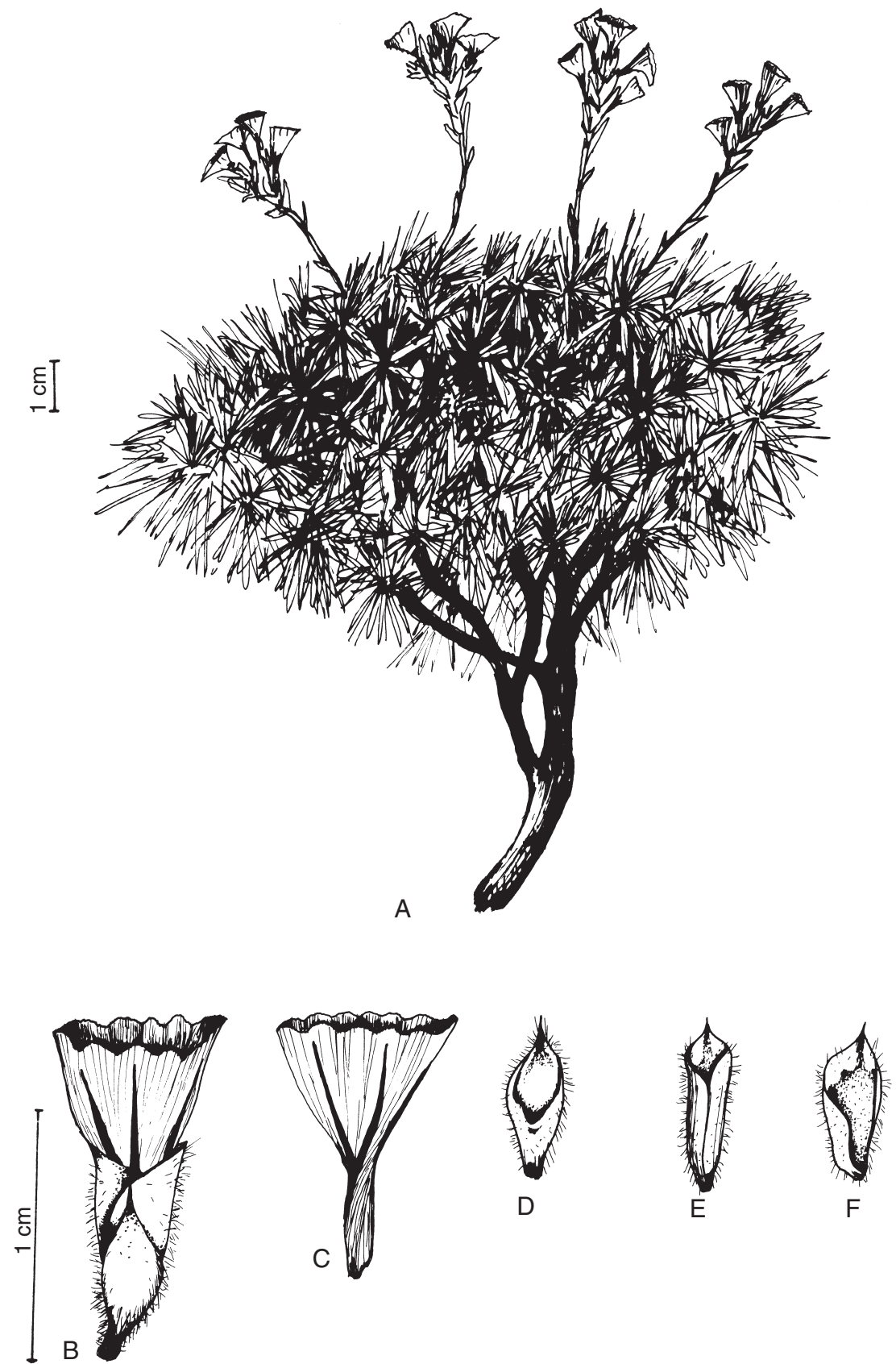

Figure 1. Acantholimon anatolicum sp. nov. (A) Habit; (B) spikelet; (C) calyx; (D) outer bracts; (E,F) inner bracts.

2002a), A. karamanicum Akaydın \& Dogan (Akaydın \& Doğan, 2002), A. yildizelicum Akaydın (Akaydın, 2002) and A. birandii Dogan \& Akaydın (Doğan \& Akaydın, 2002b).

\section{METHODS}

Since 2000, as a part of a revisional study on the genus Acantholimon in Turkey, the authors have carried out extensive field studies and collected a large number of specimens. These specimens were pressed carefully and dried using the standard techniques for laboratory analysis (Davis \& Heywood, 1973). A local population of Acantholimon, which looked close to A. strigillosum Bokhari at first glance in the field, was collected from Kuşenneti between Çayırhan in Ankara (A3). The specimens were cross-checked with the keys provided by Bokhari \& Edmondson (1982), and the Acantholimon accounts given in various floras, such as Flora Orientalis (Boissier, 1879), Flora 


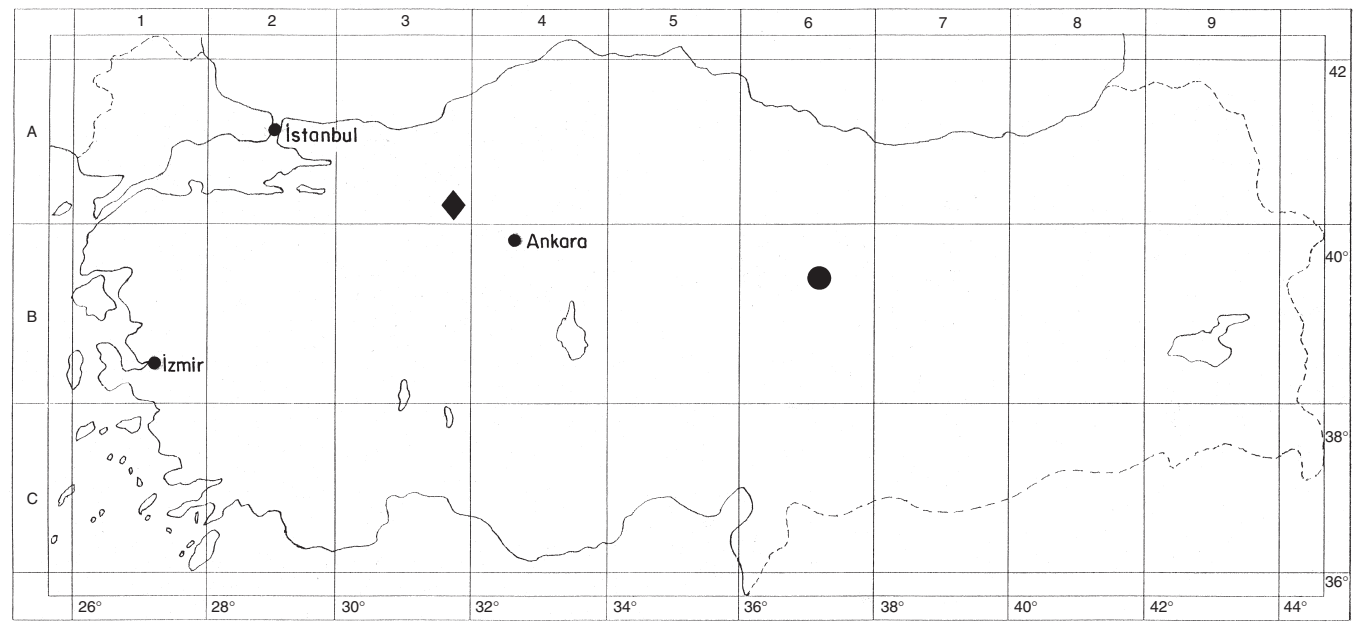

Figure 2. Distribution of $(\bullet)$ Acantholimon anatolicum sp. nov. and (๑) A. strigillosum in Turkey.

Iranica (Rechinger \& Schiman-Czeika, 1974), Flora Europaea (Moore, 1972), Flora of USSR (Komarov, 1967), and Flora of Syria, Palestine and Sinai (Post, 1933).

The specimens were then compared with the duplicates of Davis' specimens obtained from Edinburgh (E) as a gift, cited in the Flora of Turkey and the East Aegean Islands. The Supplement (Davis et al., 1988) was also consulted. Acantholimon material either collected from the field in the past two years or kept at three Turkish herbaria in Ankara (ANK, GAZI and HUB) was examined. Some specimens of A. strigillosum were also collected from the area around Hekimhan in Malatya (B6) in July and August 2001. The type specimens of E. Boissier cited in his Flora Orientalis were studied at the Boissier Herbarium in Jardine Botanic Garden, Geneva (G). The authorities are cited in accordance with Authors of Plant Names (Brummitt \& Powell, 1992).

\section{RESULTS}

\section{ACANTHOLIMON ANATOLICUM DOGAN} \& AKAYDıN SP. NOV. (FIGS 1, 2)

Holotype: Turkey A3 Ankara: Kuş Cenneti between Çayırhan and Nallıhan, deep gypsum-rich soil on mountain slopes, 500., 19.viii.2000,Doğan 2007, 2008, 2009 \& Akaydın (holo ANK).

Diagnosis: Affinis A. strigillosum sed foliis brevioribus, 5-12 mm longis, margine minute ciliatis; caules e folia exserta, 4-5 foliati; scapo $5-8 \mathrm{~cm}$ longo; spicae 15-20 mm longae, 6-12 spiculis composita; bractea florali externa breviore (4-5 $\mathrm{mm}$ longo), ovato-acuminati vel mucronati; bracteolis internis aequilongibus,
7-7.5 mm longitudine, oblongo-lanceolati, cuspidati, hyalino marginata, dorso ciliato; calycibus $10-11 \mathrm{~mm}$, infundibularibus; limbo 10-lobati, nervis limbi marginem attingentibus.

Description: Densely pulvinate glaucous shrublet. Leaves 5-12 × 0.5-1 mm, linear-triquetrous, glabrous, ciliate on margins. Scapes 5-8 cm excurrent, puberulent, with 2-3 spikes. Scales 4-5, shorter than internodes, puberulent. Spikes $15-20 \mathrm{~mm}$, imbricate to terminal. Spikelets 6-12, 1-flowered, lower ones undeveloped. Bracts unequal, green; outer bracts 4$5 \mathrm{~mm}$, ovate, pointed at apex, densely puberulent, narrowly hyaline on margins; inner bracts $7-7.5 \mathrm{~mm}$ (including aristate point c. $1 \mathrm{~mm}$ ), oblong-lanceolate, obtuse, cuspidate, with narrowly hyaline on margins especially in upper half. Calyx infundibular, 10$11 \mathrm{~mm}$, tube pilose; limb white, 10-lobed; veins expanded towards margins, not excurrent. Petals pink.

Phenology: Flowering August. Deep gypsum-rich sandy soil on dry mountain slopes.

Ecology: This new species grows on deep gypsum-rich sandy soil on open mountain slopes around Kuş Cenneti between Çayırhan and Nallıhan in Ankara (A3) with Gypsophila venusta Fenzl, Gypsophila pilosa Huds., Astragalus microcephalus Willd., various grasses of the Central Anatolian steppe.

Distribution: Central Anatolia (A3 Ankara). Endemic. Ir.-Tur. element.

Status: This new species is known only from the type locality between Çayırhan and Nallihan, where it grows on dry mountain slopes on the left side of the 


\section{A REVISED KEY TO TURKISH ACANTHOLIMON SPECIES WITH \pm DENSE TERMINAL SPIKES AND EXCURRENT SCAPES}

1. Bracts strigillose; scapes $5-6$ scaled; leaves strongly glaucous

A. strigillosum

1. Bracts glabrous or puberulous; scapes 1-5 scaled; leaves greenish or glaucous-green

2. Scapes simple, unbranched, always 1 -spiked...

3. Lower leaves strongly reflexed; inner bracts elliptic-lanceolate

$\mathbf{3}^{\prime}$. Lower leaves not strongly reflexed; inner bracts oblong-spathulate to oblong-lanceolate

2'. Scapes branched, $2(-3)$ spiked

4. Densely pulvinate; leaves $8-20 \mathrm{~mm}$.

5. Inner bracts hyaline narrowly on margin; spikelets $11-12 \mathrm{~mm}$; leaves 5-12 mm long

$\mathbf{5}^{\prime}$. Inner bracts hyaline except for vein; spikelets $13-15 \mathrm{~mm}$; leaves $15-30 \mathrm{~mm}$ long

4. Laxly to densely caespitose; leaves $15-30 \mathrm{~mm}$

A. glumaceum

6'. Lower leaves spreading or slightly reflexed; branches short and leafy

A. huetii

7. Bracts not purple-tinged; calyx densely pilose on tube up to middle of limb.

A. caesareum

road facing to Kuş Cenneti. The additional field surveys carried out by the authors in July and August 2001 and 2002, showed that the species was a very local one and distributed in an area about 10 ha. The populations seem to be small and scattered on the mountain slopes where excessive grazing and erosion are threatening the species. Therefore, it should be graded as Critically Endangered (CR) category because of its local distribution and small population size (IUCN, 2001).

Etymology: This new species is named after Anatolia where it appears to be a very local and a distinct endemic species.

\section{DISCUSSION}

A. anatolicum is certainly related to A. strigillosum and both of the species could be placed in subsect. Androsacea in sect. Staticopsis on the basis of their monomorphic leaves, infundibular calyx, and having branched terminal spikes with densely congested spikelets.

In Table 1, A. anatolicum and A. strigillosum are compared on the basis of their vegetative organs (i.e. habits, leaves, scapes and scales), reproductive organs (i.e. spikes, spikelets, bracts and calyx) and habitat preferences.

Acantholium anatolicum has shorter (5-12 mm long) and glabrous leaves, but in A. strigillosum the leaves are longer $(14-18 \mathrm{~mm})$ and covered by strigillose hairs. Acantholium anatolicum has slightly shorter (5$8 \mathrm{~cm}$ ) scapes with 4-5 scales and covered with puberulent hairs all over, but in A. strigillosum scapes are slightly longer (7-12 cm), with 5-6 scales and covered with strigillose hairs.

The type of inflorescence is a spike in both species, but they are densely branched and terminal, 15-
$20 \mathrm{~mm}$ long, having 6-12 spikelets and spikelets are imbricate, $12-13 \mathrm{~mm}$ long in A. anatolicum. In A. strigillosum the spikes are laxly branched, 15$30 \mathrm{~mm}$ long, having $2-6$ spikelets which are widely spaced and 13-15 mm long.

Acantholium anatolicum appears to have a shorter outer bract (4-5 mm long) and inner bracts (7-7.5 mm long) than A. strigillosum, in which the outer bract is 6-6.5 $\mathrm{mm}$ and the inner bracts are $7-8 \mathrm{~mm}$. In A. anatolicum the inner bracts (excluding aristate point) are as long as the calyx tube, which is shorter than the inner bracts of $A$. strigillosum.

The calyx is $10-11 \mathrm{~mm}$ and the calyx tube is longer than the limb in A. anatolicum, in which the limb is $7-8 \mathrm{~mm}$ in diameter, and the veins are brownish. In A. strigillosum the calyx is $11-12 \mathrm{~mm}$, the calyx tube is of equal length to the limb, which is $5-6 \mathrm{~mm}$ in diameter and the veins are purple.

Acantholium anatolicum appears to be quite a distinct local endemic species growing on gypsum-rich sandy soils on dry mountain slopes in Central Anatolia. This new species was probably formed by means of sympatric speciation from a common ancestor, from which $A$. strigillosum also evolved.

\section{ACKNOWLEDGEMENTS}

The authors wish to thank the Regius Keeper of the Royal Botanic Garden, Edinburgh (E) for making the duplicates of Davis' material of Acantholimon available as a gift to Prof. Musa Doğan, the Regius Keeper of the Jardine Botanic Garden Geneva (G) for making their herbarium facilities available in March 2002, the Scientific and Technical Research Council of Turkey (TUBİTAK) for their financial assistance for this revisional study of the genus Acantholimon in Turkey and Mr A. Sargin from the Ministry of Environment in Ankara for his drawing of the species. Thanks are also 
Table 1. A comparison of Acantholimon anatolicum and A. strigillosum

\begin{tabular}{|c|c|c|}
\hline & A. anatolicum & A. strigillosum \\
\hline Habit & Densely pulvinate, glaucous shrublet & $\begin{array}{l}\text { Laxly pulvinate, strongly glaucous } \\
\text { shrublet }\end{array}$ \\
\hline Leaves & $\begin{array}{l}\text { Linear-triquetrous, } 5-12 \times 0.5-1 \mathrm{~mm} \text {, } \\
\text { glabrous, ciliate on margins }\end{array}$ & $\begin{array}{l}\text { Linear-triquetrous, } 14-18 \times 1-1.2 \mathrm{~mm} \text {, } \\
\text { margins scabrid, strigillose }\end{array}$ \\
\hline Scapes & $\begin{array}{l}5-8 \mathrm{~cm} \text { long, puberulent all over, densely } \\
\text { branched, } 2-3 \text { spiked }\end{array}$ & $\begin{array}{l}\text { 7-12 cm long, strigillose, laxly branched, } \\
2-3 \text { spiked }\end{array}$ \\
\hline Scale & $\begin{array}{l}4-5 \text {, shorter than internodes, puberulent } \\
\text { all over }\end{array}$ & $\begin{array}{l}5-8 \text {, shorter than internodes, strigillose } \\
\text { all over }\end{array}$ \\
\hline Spike & $2-3,15-20 \mathrm{~mm}$ long, imbricate or terminal & 2-3, 15-30 mm long, laxly distichous \\
\hline Spikelets & $6-12$ in each spike, 1 -flowered, $12-13 \mathrm{~mm}$ & $2-6$ in each spike, 1 -flowered, $13-15 \mathrm{~mm}$ \\
\hline Bracts & Unequal, puberulent all over & Unequal, strigillose all over \\
\hline Outer bract & $\begin{array}{l}\text { 4-5 mm (including aristate point), ovate, } \\
\text { narrowly hyaline on margin }\end{array}$ & $\begin{array}{l}\text { 6-6.5 mm, broadly triangular, acute, } \\
\text { margins narrowly hyaline }\end{array}$ \\
\hline Inner bracts & $\begin{array}{l}\text { 7-7.5 mm (including aristate pointc. } 1 \mathrm{~mm} \text { ), } \\
\text { oblong-lanceolate, obtuse, cuspidate with } \\
\text { narrowly hyaline margin }\end{array}$ & $\begin{array}{l}\text { 7-8 mm oblong-lanceolate, acute, long } \\
\text { cuspidate, hyaline except for the dark } \\
\text { brown vein }\end{array}$ \\
\hline Calyx & $\begin{array}{l}\text { 10-11 mm, tube densely pilose; limb } 10 \text {-lobed, } \\
\text { white; veins } 5 \text { - brownish, pilose, expanded } \\
\text { towardsmargins, not excurrent }\end{array}$ & $\begin{array}{l}\text { 11-12 } \mathrm{mm} \text {, tube densely pilose in middle } \\
\text { region; tube equal to limb; limb } \\
\text { obscurely } 5 \text {-lobed; veins purple, } \\
\text { narrowing towards margin, excurrent }\end{array}$ \\
\hline Petals & Pink & Pink \\
\hline Flowering time & 8 & $8-9$ \\
\hline Habitat & Deep sandy gypsum-rich soil & Eroded hills \\
\hline Altitude & $500 \mathrm{~m}$ & $1100-1250 \mathrm{~m}$ \\
\hline Phytogeography & Irano-Turanian element & Irano-Turanian element \\
\hline
\end{tabular}

due to the herbaria ANK, GAZİ and HUB for making their material available.

\section{REFERENCES}

Akaydın G. 2002. A new species of Acantholimon Boiss. (A. yildizelicum sp. nov.) (Plumbaginaceae) from North Anatolia, Turkey. Nordic Journal of Botany 22(4): in press.

Akaydın G, Doğan M. 2002. A new species of Acantholimon Boiss. (Plumbaginaceae) from Western Taurus Mountains of Turkey. Israel Journal of Plant Sciences 50: 67-71.

Baytop T. 1994. A Turkish dictionary of plant names. Ankara, Turkey: Turkish History Foundation Press (in Turkish).

Boissier E. 1879. Flora Orientalis, 4. Basel, 823-854.

Bokhari MH. 1970. Materials for a Flora of Turkey XXII: Plumbaginaceae. Notes from the Royal Botanic Garden, Edinburgh 30: 295-304.

Bokhari MH. 1972a. Synopsis of Plumbaginaceae in Turkey. Notes from the Royal Botanic Garden, Edinburgh 32: 57-77.

Bokhari MH. 1972b. A brief review of stigma and pollen types in Acantholimon and Limonium. Notes from the Royal Botanic Garden, Edinburgh 32: 79-84.

Bokhari MH, Edmondson JR. 1982. Acantholimon Boiss. In: Davis PH, ed. Flora of Turkey and the East Aegean Islands, Vol. 7. Edinburgh: Edinburgh University Press, 478-502.
Brummitt RK, Powell CE, eds. 1992. Authors of Plant Names. London: Royal Botanic. Gardens, Kew.

Davis PH, Heywood VH. 1973. Principles of angiosperm taxonomy. Huntington, New York: Robert E. Kieger Publishing Co.

Davis PH, Mill RR, Tan K. 1988. Acantholimon Boiss. In: Davis PH, ed. Flora of Turkey and the East Aegean Islands, Vol. 10. Edinburgh: Edinburgh University Press, 212 pp.

Doğan M, Akaydın G. 2002a. A new species of Acantholimon Boiss. (Plumbaginaceae) from Central Anatolia, Turkey. Botanical Journal of the Linnean Society 138: 365-368.

Doğan M, Akaydın G. 2002b. A new species of Acantholimon Boiss. (A. Birandii sp. nov.) (Plumbaginaceae) from the Central Anatolian Steppe in Turkey. Nordic Journal of Botany 21: 481-484.

IUCN 2001. Red List Categories: Version 3.1. Prepared by the IUCN Species Survival Commission. Gland, Switzerland and Cambridge, UK: IUCN.

Komarov VL, ed. 1967. Flora U.R.S.S., Vol. 18. Jerusalem: Israel Program for Scientific Translations (English translation).

Moore DM. 1972. Acantholimon Boiss. In: Tutin et al. Flora Europaea, Vol. 3. Cambridge: Cambridge Universty Press, 30.

Muvaffak A. 1997. A taxonomic study on Acantholimon Boiss. (Plumbaginaceae) in. Ankara Province. Unpublished MSc. Thesis. Ankara: Middle East Technical University. 
Muvaffak A, Doğan M, Bilgin CC. 2001. Numerical taxonomic study of the. genus Acantholimon Boiss. (Plumbaginaceae) in Ankara Province. Israel Journal of Plant Sciences 49: $297-300$.
Post GE. 1933. Flora of Syria, Palestine and Sinai. Beirut: American Press, 510-511.

Reichinger KH, Schiman-Czeika H. 1974. Flora Iranica: Plumbaginaceae, no. 108. Graz-Austria. 